\title{
DISTRIBUTION, HOST RANGE AND FLIGHT PATTERN OF THE LETTUCE APHID IN NEW ZEALAND
}

\author{
M.A.W. STUFKENS and D.A.J. TEULON \\ Crop \& Food Research, Private Bag 4704, Christchurch, New Zealand \\ Corresponding author: stufkensm@crop.cri.nz.
}

\begin{abstract}
The lettuce aphid (Nasonovia ribisnigri) was first reported in New Zealand on lettuce (Lactuca sativa) in Canterbury in March 2002. During autumn 2002 , the lettuce aphid was collected in three suction traps $(7.5 \mathrm{~m}$ high) around Canterbury. Within one year it had spread to all of the main lettuce growing regions of the country, mostly as a result of transporting aphidinfested fresh lettuce or lettuce seedling transplants to these regions. It was found on its primary host, Ribes spp. (e.g. currants and gooseberries), and moved to its secondary hosts (e.g. lettuce and weeds) in late spring, having survived the winter in sexual and asexual forms. Up to 73 lettuce aphids per flower head were found on flower buds and flowers of some widely distributed weeds in New Zealand, including Crepis spp., Hieracium spp., Cichorium intybus and Lactuca virosa, during summer and autumn 2003. This infestation resulted in a number of crops being deemed unfit for marketing.
\end{abstract}

Keywords: lettuce aphid, Nasonovia ribisnigri, suction traps, flight activity, spread.

\section{INTRODUCTION}

The lettuce aphid (Nasonovia ribisnigri) is a major pest of lettuces (Lactuca sativa L.) and Ribes spp. (e.g. currants, gooseberries) in Europe where it originates (Keep \& Briggs 1971; Blackman \& Eastop 2000). In recent years this insect has spread to other continents, notably North America (Arizona) in 1998-99 (Palumbo 2000; Palumbo \& Hannan 2002), causing major problems for growers. The first record of the lettuce aphid in Australasia was in the vegetable growing area of Marshlands, on the outskirts of Christchurch, New Zealand, in March 2002 (Stufkens 2002). The country of origin of the New Zealand outbreaks is unknown, but work is in progress to ascertain this using DNA profiling (Stufkens et al. 2002).

Egg laying sexuals of lettuce aphid move on to the primary hosts, Ribes spp. (e.g. currants and gooseberries), in autumn. The eggs, which are laid around the buds, hatch in the spring and multiply on primary hosts for a few generations, causing leaf curling and decreased stem elongation. The aphids then fly on to secondary hosts, mainly liguliforous Compositae (e.g. lettuce, chicory, hawksbeard, hieracium), some Scrophulariaceae (e.g. speedwell) and Solanaceae (e.g. tobacco, petunia)(Blackman \& Eastop 2000). Lettuce aphid is found on all growth stages of the lettuce plant. Observations indicate that it causes leaf distortion and reduced vigour in seedlings, while at harvest it presents a cosmetic problem. On hawksbeard (Crepis capillaries), a common weed in New Zealand, the lettuce aphid is mainly found on the upper flower stem and flowers.

The aphid is hard to control on lettuce crops as it lives deep inside lettuce hearts where few insecticides can reach. Lettuce aphid insecticide resistance is found in several regions throughout Europe (Barber et al. 1999) and in New Zealand, initial tests have shown that the lettuce aphid is partially resistant to two insecticides (P. Workman, pers. comm.). This information may also help to identify its origin.

In New Zealand, lettuces are grown indoors and outdoors all year round, both commercially and in home gardens. Seedling transplants and fresh lettuces are transported 
throughout the country and this has been an important factor in the spread of lettuce aphid throughout New Zealand. This paper describes the distribution, host range and flight pattern of the lettuce aphid after a series of searches and surveys of lettuce plants, primary hosts and secondary hosts as well as from suction trap data.

\section{Flight trapping}

\section{METHODS}

Lettuce aphid flight activity was monitored from March 2002 until May 2003, using $7.5 \mathrm{~m}$ high suction traps at four locations in Mid and South Canterbury (Lincoln, Courtenay, Rokeby and Hilton), and one location in Hawke's Bay (Ngatarawa area, west of Hastings). The enclosed-cone suction traps contain an aerofoil fan, $305 \mathrm{~mm}$ in diameter, which draws about $60 \mathrm{~m}^{3}$ of air per minute (Johnson \& Taylor 1955; Stufkens et al. 2000). Aphid samples, collected weekly from each trap and analysed in the laboratory, showed whether lettuce aphids were present in the area and indicated seasonal flight patterns. Lettuce aphid males were also recorded to indicate when the aphids moved from the secondary host back to the primary host.

\section{Surveys}

When a lettuce aphid was first found in a suction trap, host plants were sampled around the trap area (5 km radius for 4 hours) for the presence of the lettuce aphid. Through the media, the public was regularly asked during 2002 to send aphids found on locally grown or store-bought lettuces to Crop \& Food Research, Lincoln, for identification. When a lettuce aphid was found in a sample, a visit was made to the area from which it came to assess the degree of infestation and extent of spread on both lettuces and weeds. Plant samples were collected and taken to the laboratory for identification (Roy et al. 1998). In addition, when lettuce aphid outbreaks were reported by the industry, crops in the relevant area were surveyed.

In late spring (late-November/December 2002), surveys were carried out over a period of 15 days throughout the South Island and parts of the North Island to evaluate distribution, spread and plant hosts (Fig. 2). A period of up to one hour (or until the aphid was found) was spent looking for the lettuce aphid at sites including commercial lettuce properties, home gardens and weedy areas. Lettuces were destructively sampled to see if they contained aphids and the flower heads of weeds were examined. Samples of aphids found were taken for verification in the laboratory.

Three South Island vegetable distribution centres were visited to map the transport of fresh lettuce from the original area of infestation. In December 2002, areas to which fresh lettuce had been delivered the previous autumn were searched for lettuce aphid.

Weed surveys were carried out in summer/autumn 2003 in the Canterbury region and from Wellington to Kaitaia in the North Island, looking for the lettuce aphid. Samples of lettuce aphids were collected from each site and verified in the laboratory. The presence of winged males, apterous adults and winged fourth instars was recorded.

In autumn, leaves of the primary hosts (currants and gooseberries) were sampled at 12 Canterbury properties, both commercial and domestic, for egg laying female and male lettuce aphids. Continued monitoring showed eggs around the buds of these hosts in the winter with lettuce aphids hatching from the eggs in the spring.

\section{Initial infestation and spread}

\section{RESULTS AND DISCUSSION}

The lettuce aphid was first recorded in the Marshlands area of Christchurch on 28 March 2002 after a grower, who was having problems controlling aphids on his lettuce crops, sought advice from M. Stufkens. On discovery of the lettuce aphid, samples from a suction trap at Lincoln, $20 \mathrm{~km}$ from Marshlands, were examined and it was found that one lettuce aphid had been caught in the first week of March. High numbers of lettuce aphids (500+ per lettuce) were found in lettuce crops on five properties in the Marshlands area, also during late March, suggesting that the aphid had been in the area for some time. By mid-April, 34 properties sampled in the greater Christchurch area 
were all found to have lettuce aphid infestations. By late March/April, lettuce aphid had been collected in two other suction traps in Mid-Canterbury (Fig. 1). Sampling host plants around these two traps revealed the presence of lettuce aphid on both lettuces and gooseberries in private gardens. No lettuce crops were found growing in these areas. The suction trap at Hilton (South Canterbury) first recorded the lettuce aphid in January 2003 (Fig. 1).

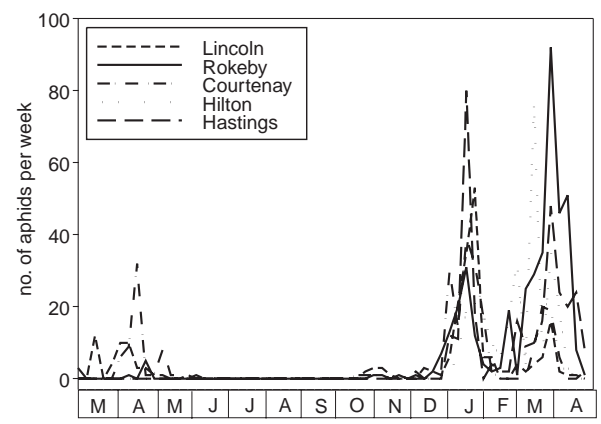

FIGURE 1: Lettuce aphid flight patterns recorded from March 2002 to April 2003 from five $7.5 \mathrm{~m}$ high suction traps. The Hastings trap was located near Hastings (Ngatarawa), Hawke's Bay, North Island, while the other four traps were in Canterbury (Hilton in the south, and Lincoln, Rokeby and Courtenay in mid Canterbury), South Island.

During March 2002, fresh lettuces from Christchurch were transported by the industry to all major cities and towns in the South Island as well as to Pukekohe in the North Island. In June 2002, high numbers of lettuce aphids were found in outdoor lettuces on one Pukekohe property, $1000 \mathrm{~km}$ north of Christchurch (Fig. 2). One truckload of fresh lettuce from Marshlands had been delivered to this property earlier in the year. Aphids were also found on an Outram property, $370 \mathrm{~km}$ south of Christchurch (Fig. 2). Again, this property had taken delivery of seedling transplants and fresh lettuce from Marshlands since February. In July the lettuce aphid was found in large numbers on a property in Richmond, Nelson, $400 \mathrm{~km}$ north of Christchurch (Fig. 2), which had been visited daily by produce trucks from Christchurch. None of the properties surrounding the affected properties were found to be infested, yet all three properties had lettuce aphids in such numbers (100+ per plant) that part or all of their crops were unmarketable.

Because the lettuce aphid lives predominantly in the heart of each lettuce, where it is not visible unless lettuces are destructively sampled, many growers surveyed were unaware of aphid infestations until they started to harvest their crops, too late to apply control measures. As a result, approximately $\$ 300,000$ worth of lettuces was lost in the Canterbury, Pukekohe, Outram and Nelson areas during the 4 months following the initial discovery of the aphid.

\section{Distribution: spring/summer 2002/03}

A December 2002 survey of the South Island covering all regions (e.g. Nelson, Marlborough, Canterbury, Otago, Southland and the West Coast) found that lettuce aphid had established in all towns to which fresh lettuce had been transported in March, except Invercargill (Fig. 2). It was also found on lettuces in home gardens in rural areas from coastal to mountain regions (e.g. Oamaru, Queenstown and Porters Pass).

In the Pukekohe region during winter/early spring 2002, lettuces were sampled and the lettuce aphid was found to have survived and spread to two other properties within $1.5 \mathrm{~km}$ of the original infestation. By December 2002, lettuce aphid was found on lettuce crops through to Auckland. 


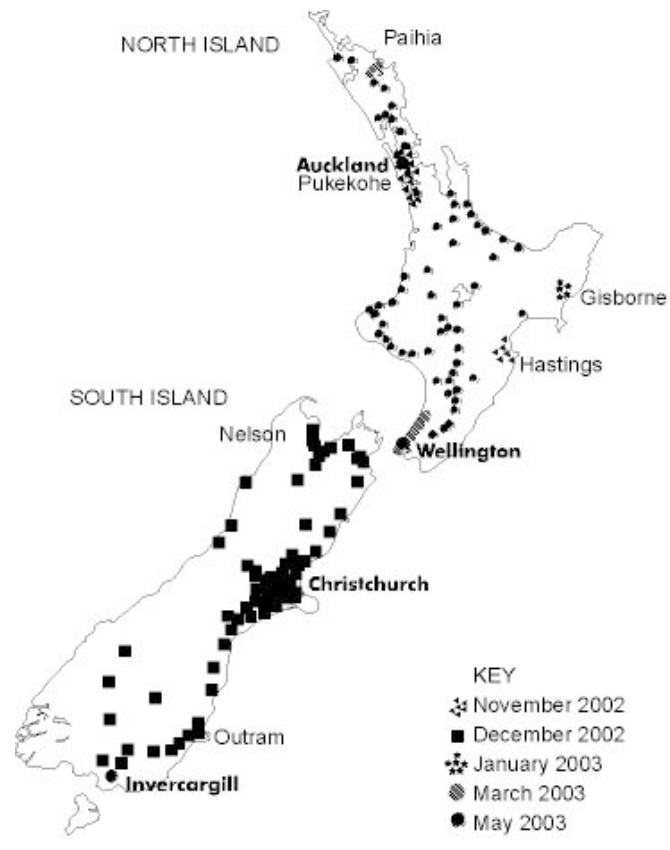

FIGURE 2: Distribution of sites where lettuce aphid was found from November 2002 to May 2003.

Large numbers of lettuce aphids (500+ per lettuce), showing they had been there for some time, were found on six properties south of Napier, Hawke's Bay, in November 2002 , over $400 \mathrm{~km}$ from any previously known infestation. The aphids were found in old winter-grown lettuces as well as in new spring plantings. A survey of regions around the Hawke's Bay area did not detect any lettuce aphid, suggesting it had arrived by transportation. Supporting this likelihood, the first winged lettuce aphid was collected in a suction trap near Hastings in the last week of November 2002 (Fig.1), long after it had established in the area.

After the survey in December 2002 showed no lettuce aphid in the Gisborne area, publicity was used in an effort to keep the area $(215 \mathrm{~km}$ from Hawke's Bay and isolated by hills) free of the aphid. However, the first lettuce aphid was found in a lettuce crop in early January 2003 (Fig. 2) and within weeks large numbers had built up over the whole region. Again, the lettuce aphid was not found in surrounding regions, suggesting that transportation of fresh lettuce was the means of spread of the pest.

\section{Distribution: autumn 2003}

In March 2003, a large area from Wellington through to Foxton (Kapiti/Horowhenua region) was found to be infested with sizeable lettuce aphid populations, despite the region being apparently free of lettuce aphid in an early December 2002 survey (12 properties sampled)(Fig. 2). In all 18 sites sampled, lettuce aphid was found. Infestation of the region was expected given that aphids can be blown in from the Nelson region on a southwest wind.

In late March 2003, the lettuce aphid was found in Paihia (Bay of Islands, over 200 km north of Auckland) on a hydroponic lettuce-growing property (Fig. 2). The property adjoins a supermarket that had disposed of aphid-contaminated lettuces from Pukekohe in a nearby skip. 
In May 2003, 64 towns in the North Island were sampled for lettuce aphid. In all the towns surveyed the lettuce aphid was commonly found on the flowers of hawksbeard (Fig. 2). In each town the lettuce aphid was found at the first site sampled except for Cambridge, National Park, Hamilton, Waihi, Katikati, Dargaville, Kerikeri and Warkworth where three to five sites were sampled before the aphid was found. Over $50 \%$ of the aphids collected were winged and of the winged aphids collected $15 \%$ were males. The most northern site that males were collected from was Kaitaia in Northland. At all sites where lettuce aphids were collected, wingless adults were also found still laying live young.

\section{Alternative hosts}

Surveys of weeds known to be hosts of the lettuce aphid (Blackman \& Eastop 2000) were carried out in Canterbury. Between December 2002 and May 2003, up to 60 lettuce aphids were found on buds and flowers of hawksbeard. Aphids were found on most hawksbeard plants examined at 50 different sites in Canterbury. Similar results were found for 341 sites out of 387 sampled in the North Island up to Kaitaia.

Smaller numbers of lettuce aphids were found on the flowers of chicory (Cichorium intybus) in Hawke's Bay and Canterbury. None have been found to date on tobacco (Nicotiana tabacum), petunia (Petunia spp.) or speedwell (Veronica).

The lettuce aphid was also found in large numbers on the buds and flowers of Hieracium (Hieracium pilosella and $H$. praealtum) and hawksbeard in the Porters Pass-Broken River region of inland Canterbury. Most Hieracium had finished flowering by January, but remaining flowers sampled in January had up to 73 lettuce aphids per flower head.

\section{Primary hosts}

Both male and egg-laying females of the lettuce aphid were found in Mid Canterbury on gooseberries and black and red currants, with black, shiny eggs laid around buds in April/May 2002 and 2003. After over-wintering, these eggs hatched in early October 2002. The aphids remained on the primary hosts, building up numbers until the end of November 2002 before all flying on to their secondary hosts. Up to 60 lettuce aphids were found on the new growing tips of gooseberries, causing curled leaves and reduced stem elongation, while only a few lettuce aphids were found on currents in spring. Many of the eggs marked in the autumn were found to be dehydrated in the winter, possibly as a result of feeding by predators.

Four egg-laying females were found in late September at Lincoln on new blackcurrant leaves, suggesting either that they were still adapting to the southern hemisphere or that egg-laying females were still being produced through the warmer winter. When these aphids were dissected no eggs were found.

\section{Flight patterns}

Figure 1 shows two distinct lettuce aphid flight peaks for the five suction traps. The first occurred in summer (January 2003), corresponding with the December harvest of lettuce crops, the end of the main Hieracium flowering period and the early flowering of hawksbeard, as temperatures rose and the ground dried out. The second peak flight in late summer/autumn (March/April 2003) corresponded with aphids moving back to their primary hosts to lay eggs (Fig. 1). Male lettuce aphids were recorded in all five suction traps in late March and April of 2002 and 2003; 42\% of all the lettuce aphids caught in the traps during April of both years were males. However, asexual lettuce aphids were found on lettuces during the winter of 2002 in Canterbury and Pukekohe, mainly in greenhouses or the warmer outdoor areas, suggesting that not all those flying in the autumn were going to primary hosts.

There was also a small flight in October-November 2002, corresponding with the lettuce aphid leaving primary host plants to fly to secondary hosts, as well as with the finish of lettuce crops grown through the winter.

\section{CONCLUSIONS}

Our extensive surveys have established that the lettuce aphid has rapidly spread throughout the lettuce growing areas of New Zealand, through both natural and human- 
assisted means, i.e. via transport of infested lettuce and seedling transplants. Transportation of infested produce to other regions has meant the lettuce aphid spread faster than it naturally would have and this is an issue that must be addressed when new pest outbreaks occur in future. Methods of controlling the lettuce aphid are likely to include a more intensive, destructive scouting system for early detection of the pest in crops and insecticidal control in early plant growth stages as little control is possible once the lettuce heart has formed. This pest has quickly caused serious economic losses for lettuce growers in New Zealand and research on integrated control of the pest has become an urgent priority.

\section{ACKNOWLEDGEMENTS}

Thanks to Callum Fletcher and Georgia-Rose Travis for assisting with the suction trap samples, and to the many lettuce growers who let us sample their crops.

\section{REFERENCES}

Barber, M.D.; Moores, G.D.; Tatchell, G.M.; Vice, W.E.; Denholm, I. 1999: Insecticide resistance in the currant-lettuce aphid, Nasonovia ribisnigri (Hemiptera: Aphididae) in the UK. Bull. Entomol. Res.: 89: 17-23.

Blackman, R.L.; Eastop, V.F. 2000: Aphids on the world's crops. John Wiley \& Sons Ltd, London, England. 644 p.

Johnson, C.G.; Taylor, L.R. 1955: The development of large suction traps for airborne insects. Annals Appl. Biol. 43: 51-62.

Keep, E.; Briggs, J.B. 1971: A survey of Ribes species for aphid resistance. Annals Appl. Biol. 68: 23-30.

Palumbo, J.C. 2000: Seasonal abundance and control of the lettuce aphid, Nasonovia ribisnigri, on head lettuce in Arizona. Vegetable Report, University of Arizona College of Agriculture, Yuma, USA.

Palumbo, J.C.; Hannan, T.A. 2002: Population growth of lettuce aphid, Nasonovia ribisnigris, on resistant butter and head lettuce cultivars. Vegetable Report, University of Arizona College of Agriculture, Yuma, USA.

Roy, B; Popay, I.; Champion, P.; James, T.; Rahman, A. 1998: An Illustrated Guide to Common Weeds of New Zealand. New Zealand Plant Protection Society, Lincoln, New Zealand. 282 p.

Stufkens, M.A.W. 2002: Lettuce aphid in New Zealand. Grower, May: 37-39.

Stufkens, M.A.W.; Teulon, D.A.J.; Nicol, D.; Fletcher, J.D. 2000: Implications of aphid flight patterns for pest management of potatoes. N.Z. Plant Prot. 53: 78-82.

Stufkens, M.A.W.; Teulon, D.A.J.; Bulman S.R. 2002: Nasonovia ribisnigri, a new aphid pest found on lettuces (Lactuca sativa L.) and Ribes spp. in Canterbury. N.Z. Plant Prot. 55: 437. 